\title{
Microwave-assisted Natural Deep Eutectic Solvents Pretreatment Followed by Hydrodistillation Coupled with GC-MS for Analysis of Essential Oil from Turmeric (Curcuma longa L.) \\ Fang-Xiang $\mathrm{Xu}^{1}$, Jing-Yu Zhang ${ }^{1}$, Jing $\mathrm{Jin}^{1}, \mathrm{Zu}-$ Guang $\mathrm{Li}^{1 *}$, Yuan-Bin She ${ }^{1 *}$, and Maw-Rong Lee ${ }^{2}$ \\ ${ }^{1}$ College of Chemical Engineering, Zhejiang University of Technology, Hangzhou 310014, CHINA \\ ${ }^{2}$ Department of Chemistry, National Chung Hsing University, Taichung 40227, TAIWAN
}

\begin{abstract}
In the past decade, natural deep eutectic solvents (NADESs) as green and sustainable extraction solvents with great potential for the efficient extraction of bioactive compounds from the plants are emerging. In this study, a microwave-assisted technology is used to prepare natural deep eutectic solvents. And natural deep eutectic solvents as pretreatment solvents coupled with microwave-assisted hydrodistillation (MAHD) for isolating essential oil (EO) derived from turmeric (Curcuma longa L.) is investigated. To improve the essential oil yield of turmeric (Curcuma longa $L_{\text {.) }}$ ) as a target, various factors affecting extraction efficiency including the type and amount of natural deep eutectic solvents, pretreatment time, pretreatment temperature and hydrodistillation (HD) time are discussed and optimized through central composite design (CCD) of the response surface methodology (RSM). The optimal conditions are as follows: natural deep eutectic solvent composed of choline chloride and oxalic acid (molar ratio with 1:1) as a pretreatment solvent, an amount of $60 \mathrm{~g}$, a pretreatment time of $5 \mathrm{~min}$, a pretreatment temperature of 84 ${ }^{\circ} \mathrm{C}$, a hydrodistillation time of $76 \mathrm{~min}$. Under the optimum conditions, the highest essential oil yield of $0.85 \%$ is achieved. Additionally, the essential oil is analyzed by using gas chromatography-mass spectrometry (GCMS), with a total of 49 compounds being identified. Through combining natural deep eutectic solvents with a microwave-assisted hydrodistillation technique, this work provides an eco-friendly extraction way of isolating essential oil, which boosts development in the monitoring other spice quality field.
\end{abstract}

Key words: natural deep eutectic solvent, microwave-assisted technology, microwave-assisted hydrodistillation, essential oil, turmeric

\section{Introduction}

Essential oils (EO) or volatile oils, also known as essences, originate from the secondary metabolism of plants and have complex chemical components ${ }^{1}$. Turmeric (Curcuma longa L.) belongs to the family Zingiberaceae, is a perennial rhizomatous shrub native to Southern Asia. At present, the cultivation of this species is also widely distributed in some African countries ${ }^{2}$. The turmeric essential oil is widely used in traditional and modern system of medicine due to the presence of several medicinal properties like antibacterial, antifungal, antiviral, antiworm, antiallergic, anti-parasitic, antinociceptive, anti-platelet, antimutagenic and antiarthritic properties $\operatorname{etc}^{3-6)}$.
Extraction method is one of prime factors that determine the quality of essential oil. Inappropriate extraction procedure can lead to the damage or alter action of chemical signature of essential oil ${ }^{7)}$. EO is generally extracted by physical methods, steam distillation, hydrodistillation(HD)

Abbreviations: EO; essential oil, DES; deep eutectic solvents, NADESs; natural deep eutectic solvents, CCD; central composite design, RSM; response surface methodology, GCMS; gas chromatography-mass spectrometry, MAHD; microwave-assisted hydrodistillation, HD; hydrodistillation, HBD; hydrogen bond donors, HBA; hydrogen bond acceptors, FT-IR; Fourier Transform Infrared, ANOVA; Analysis of variance

\footnotetext{
*Correspondence to: Zu-Guang Li, Yuan-Bin She. College of Chemical Engineering, Zhejiang University of Technology, Hangzhou 310014, CHINA

E-mail: Izg@ @jut.edu.cn (ZL), sheyb @ zjut.edu.cn (ML)

Accepted June 21, 2021 (received for review December 31, 2020)

Journal of Oleo Science ISSN 1345-8957 print / ISSN 1347-3352 online

http://www.jstage.jst.go.jp/browse/jos/ http://mc.manusriptcentral.com/jjocs
} 
or solvent extraction. On commercial scale, steam distillation or hydrodistillation is the most preferred method for the extraction of $\mathrm{EO}^{8}$. Technologies of traditional extraction are often inconvenient, energy-consuming or require a large amount of hazardous and expensive organic solvents and can alter the quality of the produced EOs due to the damage or losses of specific compounds under high temperature conditions or the presence of solvent residues ${ }^{9)}$. This encourages researchers to find substitutes and techniques based on their cost-effective criteria. Microwave dielectric heating is common in various processes in the food industry all over the world ${ }^{10)}$. Microwave-assisted hydrodistillation(MAHD) is more and more applied in EO extraction $^{11)}$. Compared to HD, MAHD is an extraction process that requires a short extraction period, low energy source, and is environmentally friendly ${ }^{12)}$.

Additionally, pretreatment is indispensable to overcome the natural recalcitrance of plant cell walls ${ }^{13,14)}$, and enhance the release of intracellular compounds. Recently, deep eutectic solvents (DESs) have emerged as a class of novel green fluids, which are composed of hydrogen bond donors (HBD) and acceptors (HBA) ${ }^{15,16)}$ to form a new solvent mixture with lower melting point than those of the individual components ${ }^{17)}$. They show many favorable properties including negligible vapor pressure, nonflammability, low toxicity, biocompatibility and the possibility of being made from renewable materials; at the same time, their physico-chemical properties can be tuned by modifying the HBA/HBD structures or by changing the molar ratio of these components ${ }^{18}$. Besides, DESs are proved to be good pretreatment solvents ${ }^{19,20)}$ which could possess the outstanding ability due of its ability in cellulose, hemicellulose and lignin disruption ${ }^{21)}$. Natural deep eutectic solvents (NADESs), which are directly composed of natural products, such as organic acids, amino acids, sugars, choline or urea, have received increasing attentions because they are composed of primary metabolites in living cells. NADESs have advantages of being composed of naturally-occurring compounds, being much more sustainable and posing practically no environmental hazards ${ }^{22-24)}$.

So far, there are three main methods available for preparing NADESs consisting of heating and stirring method $^{25)}$, evaporating method ${ }^{26)}$ and freeze drying $\operatorname{method}^{27)}$. Nevertheless the time and energy that these processes demand could be controversial with regard to the greenness of these solvents. The use of microwave radiation is one of the most promising techniques because of its advantages such as higher yields, milder reaction conditions and shorter reaction times ${ }^{28}$. As a consequence, microwave-assisted technology provides great potential of preparing natural deep eutectic solvents.

In this study, a novel extraction method that natural deep eutectic solvents of microwave-assisted preparation pretreatment followed by MAHD for extraction of essential oil from turmeric (Curcuma longa L.) was proposed. To the best of our knowledge, this type of pretreatment approach in terms of NADESs through microwave irradiation synthesis for isolating EO from turmeric has not been reported elsewhere. The NADESs based on microwave-assisted preparation were characterized by Fourier Transform Infrared (FT-IR) and a comparison of extraction efficiency between two different preparation methods was also included. The effects of this extraction method on the EO yield were systematically investigated by response surface methodology. The compositions of the EO are analyzed by using gas chromatography-mass spectrometry (GC-MS) and compared with the EO obtained from other extraction methods.

\section{Materials and Methods}

\subsection{Reagents, materials and samples}

Dry turmeric samples of Curcuma longa L. were purchased from traditional Chinese medicine shops (Taizhou, China). All the dry samples were pulverized into powder before using for experiments. Choline chloride, fructose, lactic acid, glucose, malic acid, oxalic acid and $n$-hexane of analytical grade were purchased from Aladdin Co., Ltd. (Shanghai, China). $\mathrm{C}_{8}-\mathrm{C}_{20} n$-alkanes of chromatographic grade were purchased from Sigma Chemical Co., Ltd. (St. Louis, MO, USA). Helium gas of high purity (99.999\%) was purchased from Hangzhou Special Gas Production Co. Ltd. (Hangzhou, China).

\subsection{Preparation of natural deep eutectic solvents}

Microwave-assisted technology is used to prepare NADESs. A two component mixture, HBA and HBD, with a calculated amount of deionized water was added to a glass flask and exposed to microwave $(400 \mathrm{~W})$ at $80^{\circ} \mathrm{C}$ until a homogeneous liquid was formed (15-30 min). After the preliminary synthesis tests, five types of NADESs were satisfactorily synthesized. It revealed that a significant reduction in energy and time consumption was observed comparing with the traditional preparing methods. Table 1 showed the composition, molar ratios, and symbols of NADESs used in this study.

As a comparative study, both of the HBDs and HBAs species were mixed together to synthesize NADESs at proper molar ratios with magnetic agitation at $80^{\circ} \mathrm{C}$, until a transparent and homogeneous solution was formed (2-4 h) . Then a calculated amount of deionized water was added into NADESs for experiment.

\subsection{Characterization of natural deep eutectic solvents}

FT-IR spectroscopy could provide the useful information for identifying the presence of functional groups or chemical bonds in a molecule or an interaction system. The syn- 
Table 1 The composition, molar ratios, and symbols of NADESs were used in this study.

\begin{tabular}{cccc}
\hline NADES name & HBA & HBD & Molar ratio $(\mathrm{mol} / \mathrm{mol})$ \\
\hline NADES-1 & Choline chloride & Fructose & $3: 2$ \\
NADES-2 & Choline chloride & Lactic acid & $1: 2$ \\
NADES-3 & Choline chloride & Malic acid & $1: 1$ \\
NADES-4 & Choline chloride & Glucose & $2: 1$ \\
NADES-5 & Choline chloride & Oxalic acid & $1: 1$ \\
\hline
\end{tabular}

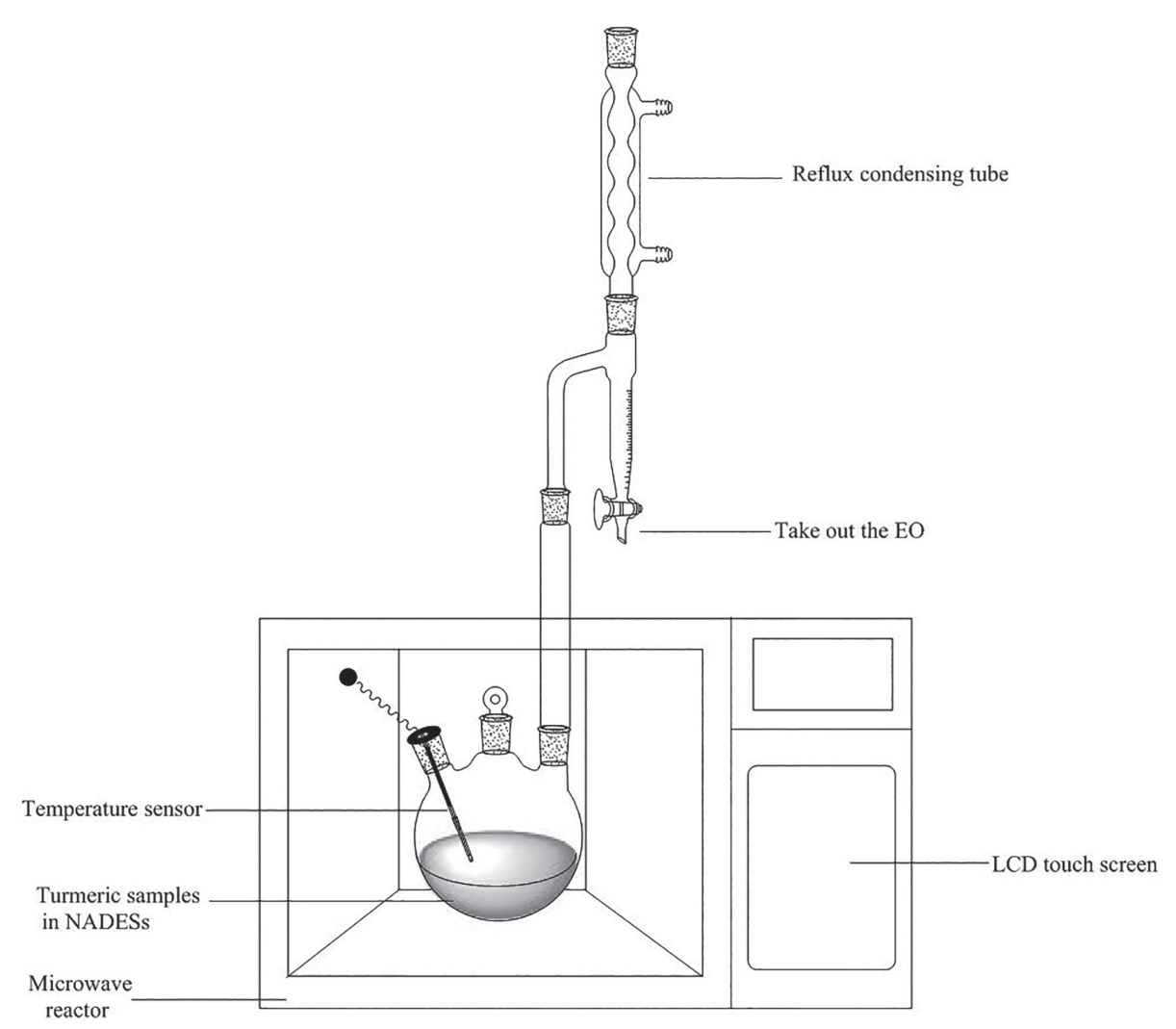

Fig. 1 The device for the NADES-based MAHD process.

thesis of NADES by microwave-assisted technology was confirmed by FT-IR Spectroscopy (T27, Bruker, Germany). The chemical characterization of these solvents was accomplished by identification of bonds present through infra-red induced absorption at a frequency related to bond vibration ${ }^{29)}$.

\subsection{NADES-based MAHD}

The NADES-based MAHD extraction of the target compounds procedure consisted of three successive processes: microwave-assisted NADES pretreatment, fast heating, and MAHD. A microwave reactor (XH-300UA, Xianghu Science and Technology Development Co. Ltd, Beijing, China) was used in experiments. The device was represented in Fig. 1.

In the first stage, $30 \mathrm{~g}$ of the sample with an accurately weighed amount of various NADESs was mixed in a 500 $\mathrm{mL}$ three-necked flask. Then the three-necked flask was placed into the microwave reactor where the mixture was pretreated by microwave irradiation with a specifically set microwave power $(600 \mathrm{~W})$, temperature $\left(84^{\circ} \mathrm{C}\right)$, and reaction time (5 min).

For the second part, $250 \mathrm{~mL}$ of water was added into the flask. The experimental apparatus sequentially constructed with a water-knockout vessel and a condenser pipe which was outside the microwave reactor was connected on the flask to achieve the purpose of collecting EO and the reflux of condensed water. The reaction conditions were microwave power $(600 \mathrm{~W})$, reaction temperature $\left(110^{\circ} \mathrm{C}\right)$, reaction time $(5 \mathrm{~min})$. This process was designed to give a momentary increase in the temperature of the reaction mixture to its boiling point. 
Finally, the purpose of the third procedure was to maintain HD. The microwave power was done with a designated value $(300 \mathrm{~W})$, while the temperature remained to be $110^{\circ} \mathrm{C}$. According to the experimental requirements, the reaction time was also set to a specified value $(76 \mathrm{~min})$. After HD, the EO was separated from aqueous phase and dried over anhydrous $\mathrm{Na}_{2} \mathrm{SO}_{4}$. Then, the samples were weighed and stored in dark tubes at $44^{\circ} \mathrm{C}$ until analysis.

The following formula was used to calculate the EO yield of the sample.

$$
\text { EO yield }(\%)=\frac{\text { weight of EO }}{\text { weight of powder }} \times 100
$$

\subsection{Experimental design and statistical analysis}

In order to obtain the maximum EO yield of turmeric by means of NADES-based MAHD method. The pretreatment time $\left(\mathrm{X}_{1}: 5-9 \mathrm{~min}\right)$, the pretreatment temperature $\left(\mathrm{X}_{2}: 60\right.$ $\left.100^{\circ} \mathrm{C}\right)$, and the HD time $\left(\mathrm{X}_{3}: 40-80 \mathrm{~min}\right)$ were selected as the three main independent variables while the response variables were the extraction yield and a central composite design (CCD) combined with response surface methodology (RSM) was employed for optimizing the operating conditions. The CCD includes a three-level full factorial design $(+1,-1)$, overlying by the center points (coded 0$)$, and the star points $(+\mathrm{a},-\mathrm{a})$. The star points establish new extremes for the low and high settings for all parameters and provide estimation of the curvature in the model ${ }^{30}$. The range of these three factors and central point were chosen in terms of the preliminary experiments. Table 2 showed the range of independent variables and their coded levels obtained after preliminary experiments and were used in the experimental design. In this CCD, these 20 randomized experiments together including six replicates at center point were employed for fitting the full quadratic equation model. The general full second-order polynomial equation is:

$$
\mathrm{Y}=\beta_{0}+\sum_{\mathrm{i}=1}^{\mathrm{n}} \beta_{\mathrm{i}} \mathrm{X}_{\mathrm{i}}+\sum_{\mathrm{i}=1}^{\mathrm{n}} \beta_{\mathrm{ii}} \mathrm{X}_{\mathrm{i}}^{2}+\sum_{\mathrm{i}<\mathrm{j}}^{\mathrm{n}} \beta_{\mathrm{ij}} \mathrm{X}_{\mathrm{i}} \mathrm{X}_{\mathrm{j}}
$$

Design-Expert software(Version 8.0) was used to carry out the design of experiments, analysis of the results and prediction of the responses. Analysis of variance (ANOVA) was used for calculating and modeling of the optimum conditions for NADES-based MAHD of EO from turmeric.

\subsection{GC-MS analysis}

Each EO sample was diluted with $n$-hexane and then added an appropriate amount of anhydrous sodium sulfate to purify the moisture in the solution. Then EO was analyzed by gas chromatography coupled to mass spectrometry (GC-MS) comprising a GC 2000 Series (Focused Photonics, Hangzhou, China) instrument coupled with a Mars 6100 ion trap mass detector using a DB-5MS capillary column $(30 \mathrm{~m} \times 0.25 \mathrm{~mm}$ id $\times 0.25 \mu \mathrm{m}$ thickness $)$. The GCMS was performed using the following operating conditions: carrier gas helium; flow velocity $0.8 \mathrm{~mL} / \mathrm{min}$; split ratio 5:1; injection volume $1 \mu \mathrm{L}$; injection temperature $250^{\circ} \mathrm{C}$; oven temperature progress holding $45^{\circ} \mathrm{C}$ for $3 \mathrm{~min}$, from $60^{\circ} \mathrm{C}$ to $90^{\circ} \mathrm{C}$ at the rate of $5^{\circ} \mathrm{C} \mathrm{min}^{-1}$ and holding for $1 \mathrm{~min}$, from $90^{\circ} \mathrm{C}$ to $250^{\circ} \mathrm{C}$ at the rate of $3^{\circ} \mathrm{C} \mathrm{min}{ }^{-1}$ and holding $250^{\circ} \mathrm{C}$ for $5 \mathrm{~min}$; ionization mode used at electronic impact $70 \mathrm{eV}$; transfer line temperature $250^{\circ} \mathrm{C}$; ion trap temperature $180^{\circ} \mathrm{C}$; manifold temperature $50^{\circ} \mathrm{C}$; and mass range $m / z 45-550$.

Identification of the constituents was based on comparison of the obtained mass spectra with those in the NIST Mass Spectral Search Program(NIST 2011 version mass spectral database; National Institute of Standards and Technology, Washington, DC, USA) connected to a Mars 6100 spectrometer and homemade library mass spectra built from pure substances and components of known oils and MS literature. The constituents were confirmed by comparison of their Kovats retention indices relative to $\mathrm{C}_{8}-$ $\mathrm{C}_{20} n$-alkanes (Sigma Chemical, St. louis, MO, USA) with those of authentic standards or in the published literature. Identification was assumed when a good match of the mass spectrum and Retention Index (RI) were achieved. Quantitative analysis in percent was performed by peak area normalization measurements ${ }^{31)}$.

\subsection{Comparison of different extraction methods}

In order to prove the method feasibility, some different methods such as MAHD and HD were applied to extract EO from the turmeric for comparison. The conditions of MAHD could be divided into two stages: (1) microwave power, temperature and reaction time were set to $600 \mathrm{~W}$, $110^{\circ} \mathrm{C}$ and $5 \mathrm{~min}$, respectively, for fast heating; (2) microwave power, temperature and reaction time were set to $300 \mathrm{~W}, 110^{\circ} \mathrm{C}$ and $76 \mathrm{~min}$, respectively, for HD. HD was traditional HD where conditions were conventional heating at

Table 2 Experimental levels of independent variables.

\begin{tabular}{lcccrrrr}
\hline \multirow{2}{*}{ Variables } & \multirow{2}{*}{ Units } & \multirow{2}{*}{ Symbol } & \multicolumn{5}{c}{ Variable levels } \\
\cline { 4 - 8 } & & & $-\alpha(-1.6)$ & -1 & 0 & +1 & $+\alpha(+1.6)$ \\
\hline pretreatment time & $\min$ & $\mathrm{X}_{1}$ & 3.64 & 5 & 7 & 9 & 10.36 \\
pretreatment temperature & ${ }^{\circ} \mathrm{C}$ & $\mathrm{X}_{2}$ & 46.36 & 60 & 80 & 100 & 113.64 \\
hydrodistillation time & $\min$ & $\mathrm{X}_{3}$ & 26.36 & 40 & 60 & 80 & 93.64 \\
\hline
\end{tabular}


$110^{\circ} \mathrm{C}$ for $4 \mathrm{~h}$.

\section{Results and Discussion}

\subsection{Characterization of natural deep eutectic solvents}

The synthetic route of NADES was shown in Fig. 2A. As an example, FT-IR was utilized for the chemical characterization of the prepared NADES composed of choline chloride and oxalic acid to confirm the existence of bonds in the individual components and between the HBA and HBD molecules. The hydrogen bond formation between the halide anion of choline chloride and oxalic acid is the major force for NADES formation. As seen in Fig. 2B, a strong, broad peak at approximate $3400 \mathrm{~cm}^{-1}$ was obtained for absorption bands of -OH, proving that there were lots of hydrogen bonds in NADES. Furthermore, the sharp peaks at around $800-1100 \mathrm{~cm}^{-1}$ were also characteristic peaks indicating formation of hydrogen bonding between the individual components ${ }^{32)}$. On the other hand, NADESs were characterized by bands in the $3150-3400 \mathrm{~cm}^{-1}$ range, which correspond to the $\mathrm{N}-\mathrm{H}$ stretching vibrations characteristic of choline chloride, which overlap with the O-H stretching

(A)

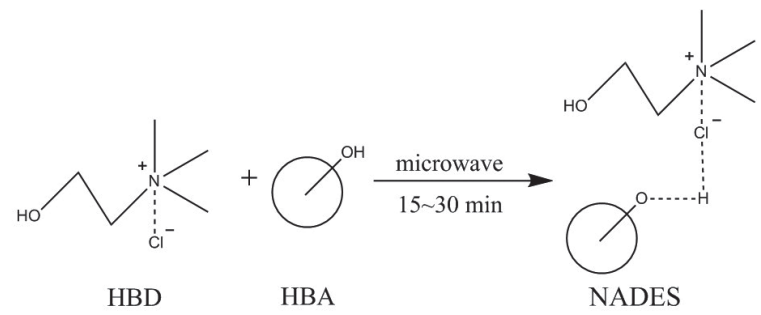

(B)

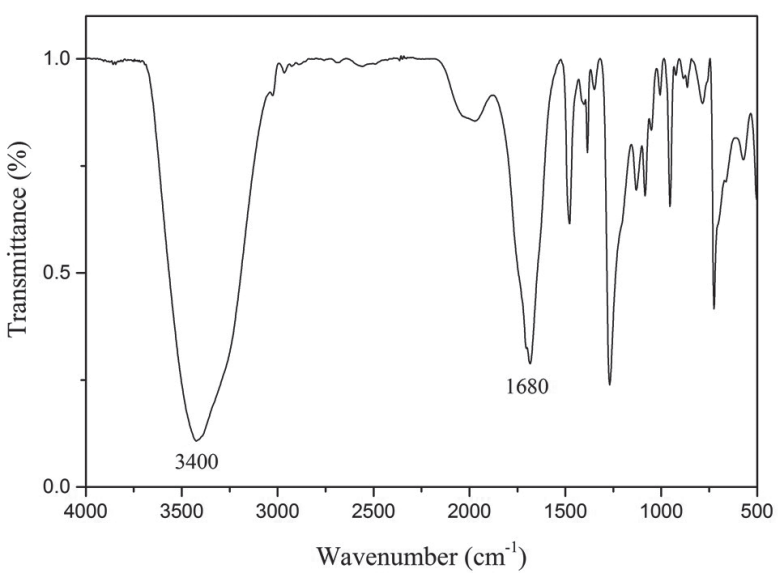

Fig. 2 The synthetic route and FT-IR spectra of natural deep eutectic solvents.

(A) The synthetic route of natural deep eutectic solvents.

(B) FT-IR spectra of natural deep eutectic solvent composed of choline chloride and oxalic acid. vibrations, thus demonstrating formation of a hydrogen bond between HBD and HBA ${ }^{33)}$. The peaks at approximate $1680 \mathrm{~cm}^{-1}$ belonged to the absorption bands of $-\mathrm{C}=\mathrm{O}$, maintaining the characteristic bands of the precursors. These bands were associated with the features of NADES comprised of choline chloride and oxalic acid. The results presented similar FT-IR spectra to those obtained in a literature search ${ }^{34)}$ when using the heating and stirring method.

\subsection{The comparison of synthesis methods of NADES}

To demonstrate the effectiveness of synthetic techniques, NADESs synthesized by microwave-assisted preparation method and the classical heating and stirring method were compared under the same extraction conditions. The EO yield for NADES composed of choline chloride and oxalic acid (molar ratio with 1:1) obtained by microwave-assisted preparation method and the classical heating and stirring method were $0.73 \%, 0.66 \%$, respectively. The result showed that both two methods have similar values of EO yield. Microwave technology was better than heating and stirring method in terms of energy saving and reduced waste time. Therefore, NADESs synthesized by microwave-assisted preparation method were used for the following experiment.

\subsection{Screening of natural deep eutectic solvents}

In this work, NADESs acted as a driving force for destroying the membrane structure of plant cells, allowing EO to diffuse out. Therefore, correct selection of NADESs type and extraction method for target compounds extracted from the sample was especially important. Five NADESs at a certain molar ratio were tested in this study by EO yield and the result was shown in Fig. 3A. The chart demonstrated that NADES-5 composed of choline chloride and oxalic acid at a molar ratio of 1:1 possessed the higher EO yields than others. The reason for this phenomenon was that DES might provide a mild acid-base catalysis mechanism which would instigate the controlled cleavage of labile ether linkages among phenylpropane units and thus led to lignin depolymerization and/or separation from the biomass $^{35)}$. In addition, oxalic acid was the most acidic among the ingredients used as HBD resulting in the best dissolving effect on the plant cell wall. Therefore, NADES-5 was chosen as the pretreatment solvent for the following experiment. Each sample was prepared and investigated in triplicate prior to analysis in this work.

\subsection{The effect of the amount of natural deep eutectic sol- vents}

The amount of NADES could affect the EO yield, which depended on the solubilizing capacity of different the amount of NADES for plant cell wall. To evaluate the influence of the amount of NADES, different amount of NADES 


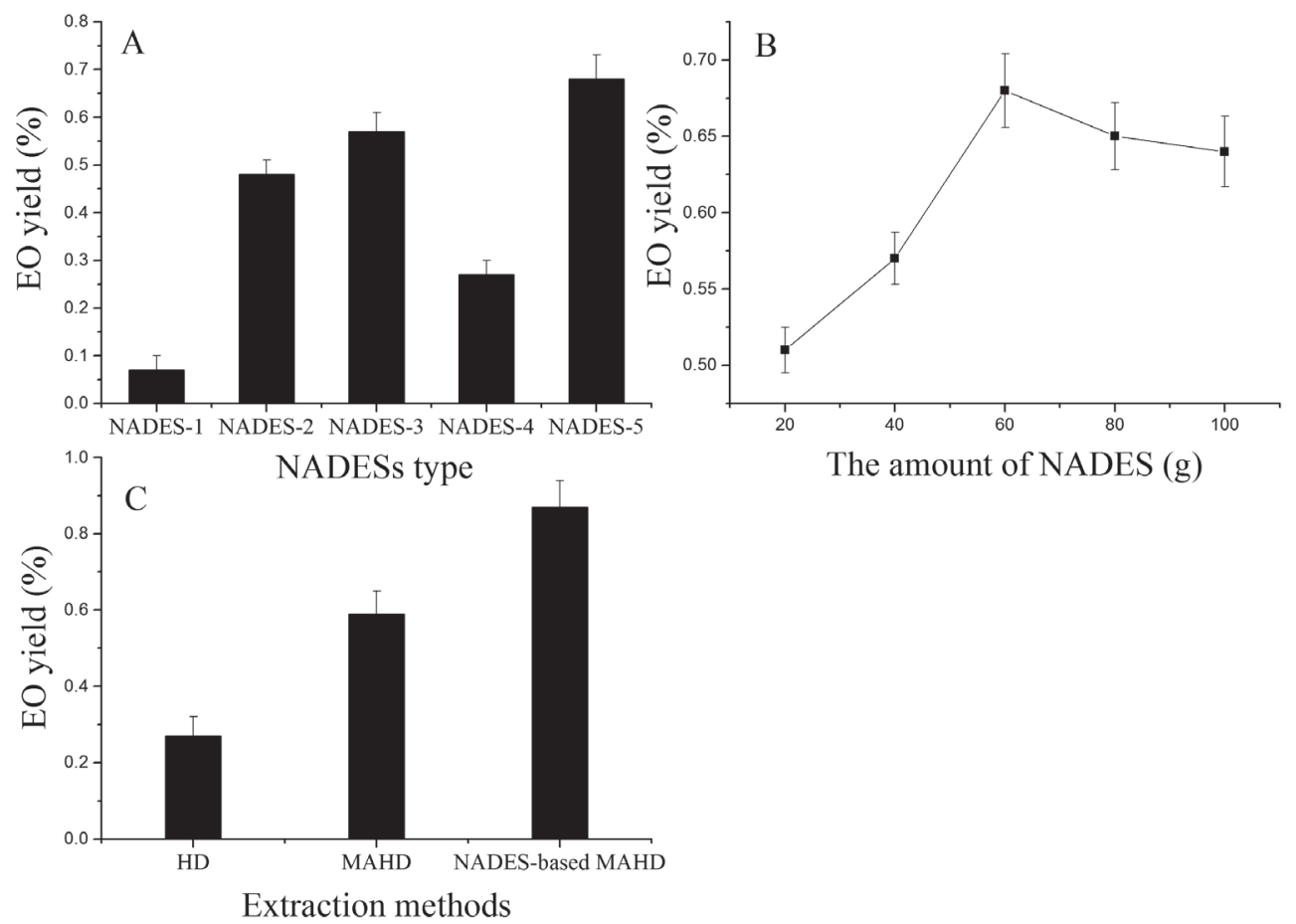

Fig. 3 Effect of NADES types, amount and extraction methods for EO yield.

(A) Effect of NADES types for EO yield. Extraction conditions: first stage: microwave power, $600 \mathrm{~W}$; temperature, $80^{\circ} \mathrm{C}$; time, $5 \mathrm{~min}$; second stage: microwave power, $600 \mathrm{~W}$; temperature, $110^{\circ} \mathrm{C}$; time, $5 \mathrm{~min}$; third stage: microwave power, $300 \mathrm{~W}$; temperature, $110^{\circ} \mathrm{C}$; time, $40 \mathrm{~min}$.

(B) Effect of NADES amount for EO yield. Extraction conditions: first stage: microwave power, $600 \mathrm{~W}$; temperature, $80^{\circ} \mathrm{C}$; time, $5 \mathrm{~min}$; second stage: microwave power, $600 \mathrm{~W}$; temperature, $110^{\circ} \mathrm{C}$; time, $5 \mathrm{~min}$; third stage: microwave power, $300 \mathrm{~W}$; temperature, $110^{\circ} \mathrm{C}$; time, $40 \mathrm{~min}$.

(C) Effect of extraction methods for EO yield. Extraction conditions: (HD): conventional heating at $110^{\circ} \mathrm{C}$ for $4 \mathrm{~h}$. (MAHD) : first stage: microwave power, $600 \mathrm{~W}$; temperature, $110^{\circ} \mathrm{C}$; time, $5 \mathrm{~min}$; second stage: microwave power, 300 $\mathrm{W}$; temperature, $110^{\circ} \mathrm{C}$; time, $76 \mathrm{~min}$. (NADES-based MAHD): first stage: microwave power, $600 \mathrm{~W}$; temperature, $84^{\circ} \mathrm{C}$; time, $5 \mathrm{~min}$; second stage: microwave power, $600 \mathrm{~W}$; temperature, $110^{\circ} \mathrm{C}$; time, $5 \mathrm{~min}$; third stage: microwave power, $300 \mathrm{~W}$; temperature, $110^{\circ} \mathrm{C}$; time, $76 \mathrm{~min}$.

$(20,40,60,80,100 \mathrm{~g})$ were investigated in the same experimental conditions. As can be seen in Fig. 3B, the EO yield of the turmeric increased with the amount of NADES from 20 up to $60 \mathrm{~g}$ because the amount of NADES was too small to be in full contact with the powder when the NADES amount was less than $60 \mathrm{~g}$. However, when the amount of NADES was over $60 \mathrm{~g}$, the yield kept declining steadily. This was due to the fact that NADES liquids had limited solvent capacity for the plant cell wall to some extent. Besides, adding NADES a lot would affect the mass transfer and reduce the yield of EO on account of the viscosity of NADES. Thus, $60 \mathrm{~g}$ was selected as the optimal amount of NADES for further experiments.

\subsection{Optimization of the extraction conditions by RSM}

\subsubsection{Fitting the model}

RSM was a fast and economical mathematical tool which reasonably investigated the influences of independent factors and their interaction on the response variable. Re- sponse surface optimization was more advantageous than the traditional single parameter optimization in that it saved time, space and raw material ${ }^{36)}$. Microwave-assisted NADES pretreatment followed by HD extraction of EO from turmeric was optimized using RSM. To examine the combined effect of three different independent variables (pretreatment time, pretreatment temperature, and HD time) on the EO yield, 20 experiments were performed. The experimental design, together with experimental data and predicted responses, was provided in Table 3. According to Table 3, the EO yields ranged from 0.44 to $0.83 \%$, and the maximum yield was obtained at pretreatment time: 5 min, pretreatment temperature: $100^{\circ} \mathrm{C}$, and HD time of $80 \mathrm{~min}$.

The model established by second-order polynomial regression equation could replace the experimental real point to explain response results. This mathematical regression model was shown below in terms of coded levels $^{37)}$ : 
Table 3 Central composite design (CCD) matrix with the actual responses and predicted values for yield of essential oil from turmeric.

\begin{tabular}{rrrccc}
\hline \multirow{2}{*}{ Run } & \multicolumn{3}{c}{ Independent variable } & \multicolumn{2}{c}{ Response (yield; \%) } \\
\cline { 2 - 6 } & $\mathrm{X}_{1}(\mathrm{~min})$ & $\mathrm{X}_{2}\left({ }^{\circ} \mathrm{C}\right)$ & $\mathrm{X}_{3}(\mathrm{~min})$ & Experimental & Predicted \\
\hline 1 & 5.00 & 60.00 & 40.00 & 0.44 & 0.43 \\
2 & 9.00 & 60.00 & 40.00 & 0.51 & 0.50 \\
3 & 5.00 & 100.00 & 40.00 & 0.49 & 0.48 \\
4 & 9.00 & 100.00 & 40.00 & 0.41 & 0.41 \\
5 & 5.00 & 60.00 & 80.00 & 0.79 & 0.77 \\
6 & 9.00 & 60.00 & 80.00 & 0.67 & 0.67 \\
7 & 5.00 & 100.00 & 80.00 & 0.83 & 0.82 \\
8 & 9.00 & 100.00 & 80.00 & 0.58 & 0.58 \\
9 & 3.64 & 80.00 & 60.00 & 0.71 & 0.73 \\
10 & 10.36 & 80.00 & 60.00 & 0.58 & 0.58 \\
11 & 7.00 & 46.36 & 60.00 & 0.63 & 0.65 \\
12 & 7.00 & 113.64 & 60.00 & 0.61 & 0.61 \\
13 & 7.00 & 80.00 & 26.36 & 0.27 & 0.28 \\
14 & 7.00 & 80.00 & 93.64 & 0.7 & 0.71 \\
15 & 7.00 & 80.00 & 60.00 & 0.8 & 0.79 \\
16 & 7.00 & 80.00 & 60.00 & 0.81 & 0.79 \\
17 & 7.00 & 80.00 & 60.00 & 0.77 & 0.79 \\
18 & 7.00 & 80.00 & 60.00 & 0.8 & 0.79 \\
19 & 7.00 & 80.00 & 60.00 & 0.77 & 0.79 \\
20 & 7.00 & 80.00 & 60.00 & 0.79 & 0.79 \\
\hline
\end{tabular}

$$
\begin{aligned}
\mathrm{Y}= & +0.79-0.044 * \mathrm{X}_{1}-9.785 \mathrm{E}-0.03 * \mathrm{X}_{2}+0.13 * \mathrm{X}_{3}- \\
& 0.035 * \mathrm{X}_{1} * \mathrm{X}_{2}-0.045 * \mathrm{X}_{1} * \mathrm{X}_{3}-0.047 * \mathrm{X}_{1}^{2}-0.056 \\
& * \mathrm{X}_{2}^{2}-0.10 * \mathrm{X}_{3}^{2}
\end{aligned}
$$

where $\mathrm{Y}$ was the EO extraction yield $(\%, \mathrm{w} / \mathrm{w}), \mathrm{X}_{1}$ was the pretreatment time $(\mathrm{min}), \mathrm{X}_{2}$ was pretreatment temperature $\left({ }^{\circ} \mathrm{C}\right)$, and $\mathrm{X}_{3}$ was the $\mathrm{HD}$ time $(\mathrm{min})$.

Table 4 showed analysis of variance (ANOVA) for the model. The $p$-value less than 0.05 had significant effects on the yield of EO, while values greater than 0.05 indicated that the model terms were not significant ${ }^{38)}$. The coefficient of determination ( $\mathrm{R}$-Squared) of the predicted model was 0.9937 , along with non-significant lack-of-fit $(p>0.05)$, suggesting a good fit, the predicted model seemed to reasonably represent the observed values. Therefore, the response was sufficiently accounted for by the model. The significance of each coefficient was determined using the F-test and $p$-value. On the basis of ANOVA results, $\mathrm{X}_{1}, \mathrm{X}_{3}$, $\mathrm{X}_{1} \mathrm{X}_{2}$, and $\mathrm{X}_{1} \mathrm{X}_{3}$ had significant effects on the EO yield $(p$ value less than 0.05 ).

3.5.2 Analysis of response surface

The RSM was taken as an optimization tool to visualize the effect of the independent variables. The three-dimen- sional response surface showed these effects of the mutual interaction of independent variables. According to Fig. 4, the regression model was used to depict the interactive effects of three operational parameters for extraction yield of $\mathrm{EO}^{37)}$.

The 3D response surface plot of the combined effects of pretreatment time and pretreatment temperature on the yield of EO was depicted in Fig. 4A indicating that lower pretreatment time led to higher yield of EO. On the one hand, the yield of EO decreased with decrease in pretreatment time. The reason for this phenomenon was the formation of esters (monoester or cross-linked diester) between hydroxyl groups of cellulose with oxalic acid, which can prevent the dissolution and hydrolysis of cellulose ${ }^{39)}$ after the long pretreatment time. On the other hand, the yield was increased when the pretreatment temperature increased from $70^{\circ} \mathrm{C}$ to $84^{\circ} \mathrm{C}$. However, further increase in pretreatment temperature could have a negative impact on the yield of EO. Too high temperature had many disadvantages involving the high consumption of energy and the loss of the highly volatile low-boiling-point compounds. Taking into account the above results, it could be inferred that the maximum EO yield occured at low pretreatment 
F.-X. Xu, J.-Y. Zhang, J. Jin et al.

Table 4 Analysis of variance(ANOVA) for the experiments.

\begin{tabular}{ccccccc}
\hline Source & Sum of squares & $\mathrm{df}$ & Mean squares & F-value & $P$-value & Significance \\
\hline Model & 0.48 & 9 & 0.053 & 175.10 & $<0.0001$ & significant \\
$\mathrm{X}_{1}$ & 0.026 & 1 & 0.026 & 86.60 & $<0.0001$ & \\
$\mathrm{X}_{2}$ & $1.308 \mathrm{E}-003$ & 1 & $1.308 \mathrm{E}-003$ & 4.32 & 0.0645 & \\
$\mathrm{X}_{3}$ & 0.22 & 1 & 0.22 & 734.32 & $<0.0001$ & \\
$\mathrm{X}_{1} \mathrm{X}_{2}$ & $9.800 \mathrm{E}-003$ & 1 & $9.800 \mathrm{E}-003$ & 32.34 & 0.0002 & \\
$\mathrm{X}_{1} \mathrm{X}_{3}$ & 0.016 & 1 & 0.016 & 53.46 & $<0.0001$ & \\
$\mathrm{X}_{2} \mathrm{X}_{3}$ & 0.000 & 1 & 0.000 & 0.000 & 1.0000 & \\
$\mathrm{X}_{1}{ }^{2}$ & 0.032 & 1 & 0.032 & 106.02 & $<0.0001$ & \\
$\mathrm{X}_{2}{ }^{2}$ & 0.045 & 1 & 0.045 & 149.43 & $<0.0001$ & \\
$\mathrm{X}_{3}^{2}$ & 0.16 & 1 & 0.16 & 512.27 & $<0.0001$ & \\
Residual & $3.030 \mathrm{E}-003$ & 10 & $3.030 \mathrm{E}-004$ & & & \\
Lack of Fit & $1.630 \mathrm{E}-003$ & 5 & $3.260 \mathrm{E}-004$ & 1.16 & 0.4357 & not significant \\
Pure Error & $1.400 \mathrm{E}-003$ & 5 & $2.800 \mathrm{E}-004$ & & & \\
Cor Total & 0.48 & 19 & & & & \\
R-Squared & 0.99 & & & & & \\
Adj R-Squared & 0.99 & & & & & \\
Pred R-Squared & 0.97 & & & & & \\
\hline
\end{tabular}

(A)

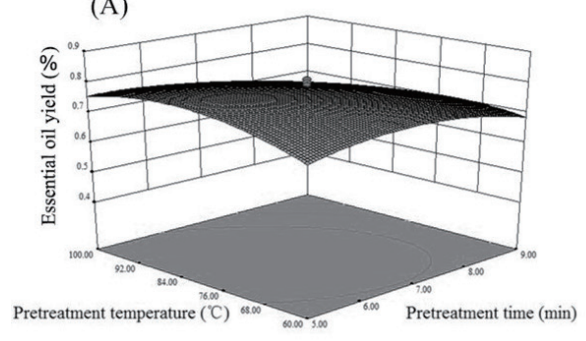

(B)

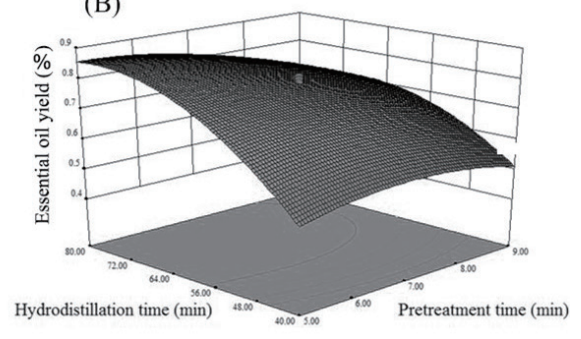

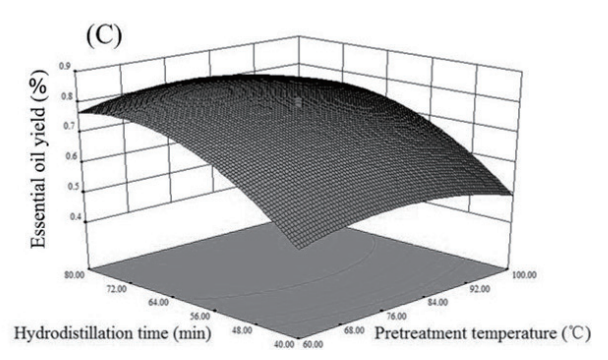

Fig. 4 Response surface plot showing the (A) the interactive effect of pretreatment time and pretreatment temperature on EO yield; (B) the interactive effect of pretreatment time and hydrodistillation time on EO yield; (C) the interactive effect of hydrodistillation time and pretreatment temperature on EO yield.

time and higher pretreatment temperature.

The combined effect of the pretreatment time and the $\mathrm{HD}$ time on the EO yield is indicated by Fig. 4B. The HD time exhibited a significant effect on the EO yield, whereas the effect of the pretreatment time was weaker. The EO yield increased linearly when the temperature ranged from 60 to $74 \mathrm{~min}$, but the yield decreased when the time was higher than 74 min. Thus, the maximum EO yield of tur- meric was obtained at high level of HD time and low level of the pretreatment time.

Figure $4 \mathrm{C}$ showed the interaction effects of $\mathrm{HD}$ time and pretreatment temperature on the extraction yield of essential oil. Overall, under all the extraction time, the extraction yields increased with the increase in HD time. The increase in extraction time didn' t have a significant effect on the EO yields at low temperatures $\left(60-70^{\circ} \mathrm{C}\right)$. However, at 
high temperature $\left(70-84^{\circ} \mathrm{C}\right)$, increasing the extraction time would lead to an increase in the yield of EO. The highly viscous DESs showed very large viscosity decreases with increasing temperature ${ }^{40}$. The temperature had a large effect on NADES viscosity, and thus, highly viscous NADESs, which cannot be used for practical purposes at close to ambient conditions, could be considered for technical applications at higher temperature. In order to speed up the mass transfer rate and improve the extraction yield, the higher extraction yields were observed at high temperature and long HD time.

3.5.3 Validation of the models

In view of the above results, the selected variables were further optimized by using Design-Expert. The software identified the following optimum conditions: 5 ( $\mathrm{min}$ ) pretreatment time $\left(\mathrm{X}_{1}\right)$, pretreatment temperature of $84\left({ }^{\circ} \mathrm{C}\right)$ $\left(\mathrm{X}_{2}\right)$, and 76 min of HD time $\left(\mathrm{X}_{3}\right)$. Furthermore, the validity of the model was checked and the experimental value $(0.85 \%)$ was closed with the predicted values $(0.86 \%)$. Therefore, the extraction conditions from RSM models could be considered to be reliable and reasonable.

To ensure the repeatability of the results in extraction of EO from turmeric using NADESs, the critical experiments were replicated three times. The uncertainty of the results was found to be within $\pm 2 \%$.

\subsection{The comparison of different methods}

According to Fig. 3C, NADES-based MAHD had the highest EO yield in comparison with other two methods, which indicated that NADESs for the pretreatment of turmeric had a remarkable impact on the increase of $\mathrm{EO}$ yields.

Quantitative analyses of turmeric oil were carried out using GC-MS and the total ion chromatograms were shown in Fig. 5. The relative level of each component was calculated by comparing its peak area with the total area that was calculated from the detected peaks ${ }^{41}$. The EO compounds obtained by different methods and the relative peak area of each identified compound were presented in Table 5. A total number of 49 compounds were identified by the three extraction methods. Simultaneously, 39, 24 and 21 compounds were identified by NADES-based MAHD, MAHD, HD methods, which accounted for $98.22 \%$, $98.17 \%$, and $98.56 \%$, respectively, of the essential oil extracted from the turmeric. There were more compounds present in EOs obtained by NADES-based MAHD compared with those obtained by MAHD and HD suggesting the effectiveness of NADESs pretreatment stage.

In the light of Table 5, the major components were ar-tumerone $(25.78 \%), \alpha$-tumerone $(16.16 \%)$ in the essential oils obtained by NADES-based MAHD which are principle compounds of turmeric oil in line with previous reports ${ }^{42)}$ contributing to the strong fragrance. In the same time, the contents of ar-tumerone, $\alpha$-tumerone are $31.35 \%, 21.38 \%$ by MAHD and $34.69 \%, 18.66 \%$ by HD of turmeric oil, respectively.

The remaining major components found in the EO were $\alpha$-himachalene (7.49\%), alloaromadendrene (5.87\%), $\gamma$-muurolene $(4.74 \%), \delta$-selinene $(4.53 \%)$, by way of NADES-based MAHD. The EO of turmeric had $\alpha$-curcumene (3.78\%), $\alpha$-zingiberene(4.66\%), $\alpha$-selinene $(6.98 \%)$, germacrone $(13.32 \%)$ as other major constituents

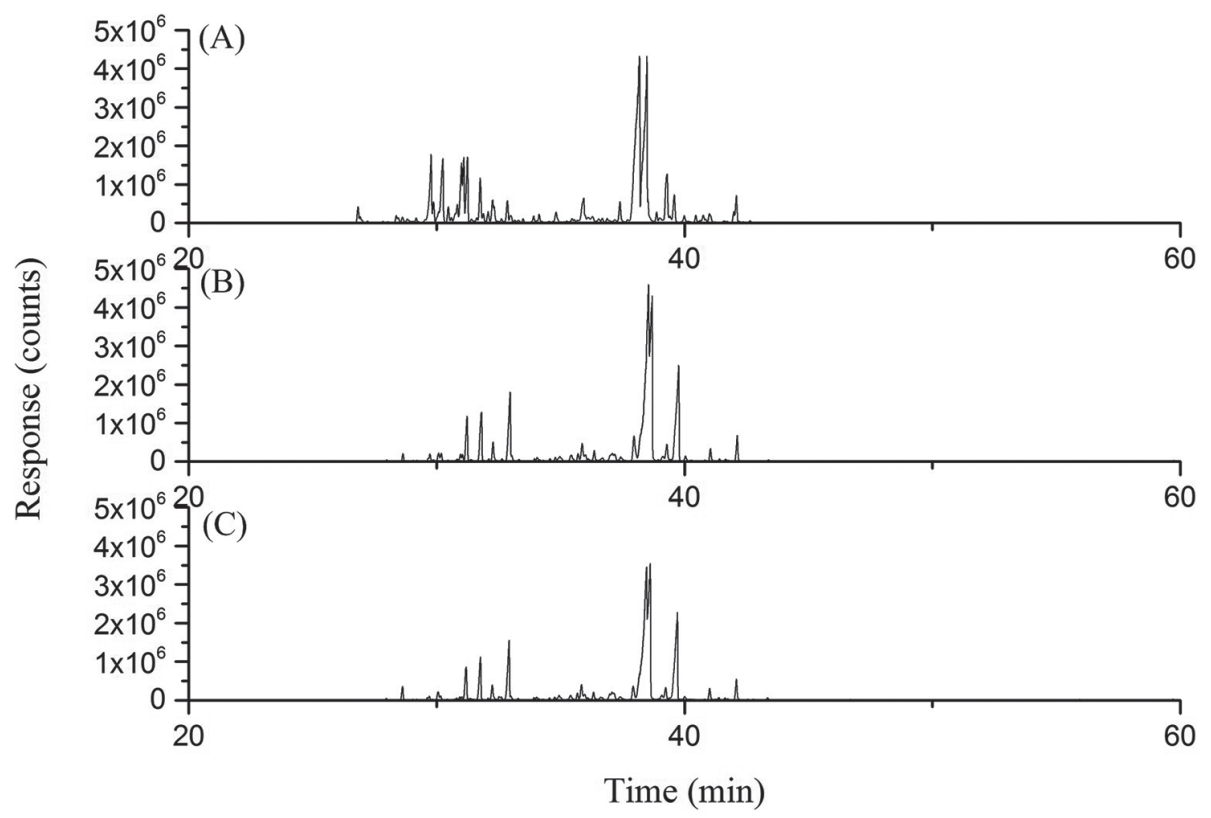

Fig. 5 The total ion chromatograms of EO obtained from three extraction methods.

(A) NADES-based MAHD; (B) MAHD; (C)HD. 
F.-X. Xu, J.-Y. Zhang, J. Jin et al.

Table 5 Chemical compositions of EO from the turmeric.

\begin{tabular}{|c|c|c|c|c|c|c|c|c|c|c|}
\hline \multirow[b]{2}{*}{ NO. } & \multirow[b]{2}{*}{$\begin{array}{l}\text { Retention } \\
\text { time (min) }\end{array}$} & \multirow[b]{2}{*}{ Compound name } & \multirow[b]{2}{*}{ Formula } & \multirow[b]{2}{*}{ CAS\# } & \multirow[b]{2}{*}{ MW } & \multirow[b]{2}{*}{$\mathrm{RI}^{\mathrm{a}}\left(\mathrm{RI}^{\mathrm{b}}\right)$} & \multirow[b]{2}{*}{$\begin{array}{l}\text { ID } \\
\text { method }\end{array}$} & \multicolumn{3}{|c|}{ Relative peak area $(\%)$} \\
\hline & & & & & & & & $\begin{array}{l}\text { NADES-based } \\
\text { MAHD }\end{array}$ & MAHD & HD \\
\hline 1 & 21.48 & Carvotanacetone & $\mathrm{C}_{10} \mathrm{H}_{16} \mathrm{O}$ & $499-71-8$ & 152 & $1247(1247)$ & MS, RI & 0.45 & ND & ND \\
\hline 2 & 23.37 & Thymol & $\mathrm{C}_{10} \mathrm{H}_{14} \mathrm{O}$ & 89-83-8 & 150 & $1292(1292)$ & MS, RI & 0.11 & ND & ND \\
\hline 3 & 25.86 & Eugenol & $\mathrm{C}_{10} \mathrm{H}_{12} \mathrm{O}_{2}$ & $97-53-0$ & 164 & 1351(1351) & MS, RI & ND & ND & 1.49 \\
\hline 4 & 26.83 & Ylangene & $\mathrm{C}_{15} \mathrm{H}_{24}$ & $14912-44-8$ & 204 & 1374(1373) & MS, RI & 1.04 & ND & ND \\
\hline 5 & 26.91 & $\beta$-Cubebene & $\mathrm{C}_{15} \mathrm{H}_{24}$ & $17699-14-8$ & 204 & $1376(1381)$ & MS, RI & 0.55 & ND & ND \\
\hline 6 & 28.45 & $\alpha$-Cedrene & $\mathrm{C}_{15} \mathrm{H}_{24}$ & $469-61-4$ & 204 & $1401(1404)$ & MS, RI & 0.32 & ND & 0.29 \\
\hline 7 & 28.61 & Caryophyllene & $\mathrm{C}_{15} \mathrm{H}_{24}$ & $87-44-5$ & 204 & $1418(1417)$ & MS, RI & 0.42 & 0.65 & 1.37 \\
\hline 8 & 28.82 & $\alpha$-Gurjunene & $\mathrm{C}_{15} \mathrm{H}_{24}$ & $489-40-7$ & 204 & $1422(1419)$ & MS, RI & 0.16 & ND & ND \\
\hline 9 & 29.17 & Aromadendrene & $\mathrm{C}_{15} \mathrm{H}_{24}$ & 109119-91-7 & 204 & $1431(1434)$ & MS, RI & 0.23 & ND & ND \\
\hline 10 & 29.21 & trans- $\alpha$-Bergamotene & $\mathrm{C}_{15} \mathrm{H}_{24}$ & $13474-59-4$ & 204 & $1432(1433)$ & MS, RI & ND & 0.18 & ND \\
\hline 11 & 29.77 & $\alpha$-Himachalene & $\mathrm{C}_{15} \mathrm{H}_{24}$ & $3853-83-6$ & 204 & $1445(1448)$ & MS, RI & 7.49 & ND & ND \\
\hline 12 & 30.08 & $(E)$ - $\beta$-Farnesene & $\mathrm{C}_{15} \mathrm{H}_{24}$ & $28973-97-9$ & 204 & $1453(1454)$ & MS, RI & ND & 0.83 & ND \\
\hline 13 & 30.25 & Alloaromadendrene & $\mathrm{C}_{15} \mathrm{H}_{24}$ & $25246-27-9$ & 204 & $1455(1458)$ & MS, RI & 5.87 & 0.76 & ND \\
\hline 14 & 30.47 & $\beta$-Selinene & $\mathrm{C}_{15} \mathrm{H}_{24}$ & $17066-67-0$ & 204 & $1463(1465)$ & MS, RI & 1.40 & ND & ND \\
\hline 15 & 30.83 & $\gamma$-Gurjunene & $\mathrm{C}_{15} \mathrm{H}_{24}$ & $22567-17-5$ & 204 & $1472(1473)$ & MS, RI & 1.24 & ND & ND \\
\hline 16 & 30.96 & $\gamma$-Muurolene & $\mathrm{C}_{15} \mathrm{H}_{24}$ & $30021-74-0$ & 204 & $1474(1473)$ & MS, RI & 4.74 & 1.02 & 0.48 \\
\hline 17 & 31.00 & $\delta$-Selinene & $\mathrm{C}_{15} \mathrm{H}_{24}$ & $28624-23-9$ & 204 & $1476(1475)$ & MS, RI & 4.53 & $\mathrm{ND}$ & ND \\
\hline 18 & 31.09 & Acoradiene & $\mathrm{C}_{15} \mathrm{H}_{24}$ & $24048-44-0$ & 204 & $1478(1471)$ & MS, RI & 3.99 & ND & ND \\
\hline 19 & 31.19 & $\alpha$-Curcumene & $\mathrm{C}_{15} \mathrm{H}_{22}$ & $644-30-4$ & 202 & $1481(1476)$ & MS, RI & 0.66 & 3.78 & 3.71 \\
\hline 20 & 31.40 & $\alpha$-Muurolene & $\mathrm{C}_{15} \mathrm{H}_{24}$ & $31983-22-9$ & 204 & $1485(1488)$ & MS, RI & 0.21 & ND & ND \\
\hline 21 & 31.61 & $\alpha$-Selinene & $\mathrm{C}_{15} \mathrm{H}_{24}$ & $5951-67-7$ & 204 & 1491(1494) & MS, RI & 0.21 & ND & ND \\
\hline 22 & 31.75 & $\beta$-Himachalene & $\mathrm{C}_{15} \mathrm{H}_{24}$ & $1461-03-6$ & 204 & 1494(1499) & MS, RI & 3.07 & ND & ND \\
\hline 23 & 31.77 & $\alpha$-Zingiberene & $\mathrm{C}_{15} \mathrm{H}_{24}$ & $495-60-3$ & 204 & $1495(1496)$ & MS, RI & ND & 4.66 & 4.96 \\
\hline 24 & 31.89 & Curzerene & $\mathrm{C}_{15} \mathrm{H}_{24}$ & $15423-57-1$ & 204 & 1497(1498) & MS, RI & 0.51 & ND & ND \\
\hline 25 & 32.25 & Valencene & $\mathrm{C}_{15} \mathrm{H}_{24}$ & $4630-7-3$ & 204 & $1507(1501)$ & MS, RI & 1.45 & 1.62 & 1.66 \\
\hline 26 & 32.63 & $\delta$-Cadinene & $\mathrm{C}_{15} \mathrm{H}_{24}$ & $483-76-1$ & 204 & $1517(1515)$ & MS, RI & 0.21 & 0.30 & ND \\
\hline 27 & 32.92 & $\beta$-Sesquiphellandrene & $\mathrm{C}_{15} \mathrm{H}_{24}$ & $20307-83-9$ & 204 & $1524(1523)$ & MS, RI & ND & ND & 7.14 \\
\hline 28 & 32.96 & $\alpha$-Selinene & $\mathrm{C}_{15} \mathrm{H}_{24}$ & $473-13-2$ & 204 & $1525(1517)$ & MS, RI & 0.54 & 6.98 & ND \\
\hline 29 & 33.32 & $\beta$-Bisabolene & $\mathrm{C}_{15} \mathrm{H}_{24}$ & $495-61-4$ & 204 & $1534(1525)$ & MS, RI & ND & 0.25 & ND \\
\hline 30 & 33.49 & Eudesma-3,7(11)-diene & $\mathrm{C}_{15} \mathrm{H}_{24}$ & 6813-21-4 & 204 & $1539(1540)$ & MS, RI & 0.23 & ND & ND \\
\hline 31 & 33.91 & Calamenene & $\mathrm{C}_{15} \mathrm{H}_{22}$ & $483-77-2$ & 202 & $1550(1542)$ & MS, RI & 0.38 & ND & ND \\
\hline 32 & 34.79 & Cedrol & $\mathrm{C}_{15} \mathrm{H}_{26} \mathrm{O}$ & $77-53-2$ & 222 & $1572(1573)$ & MS & 0.88 & 0.74 & 0.88 \\
\hline 33 & 34.82 & Spathulenol & $\mathrm{C}_{15} \mathrm{H}_{24} \mathrm{O}$ & $6750-60-3$ & 220 & $1573(1570)$ & MS, RI & 0.41 & ND & ND \\
\hline 34 & 35.41 & Longiborneol & $\mathrm{C}_{15} \mathrm{H}_{26} \mathrm{O}$ & $465-24-7$ & 222 & $1588(1592)$ & MS, RI & 2.22 & 0.84 & 0.78 \\
\hline 35 & 35.70 & $c i s$ - $\beta$-Elemenone & $\mathrm{C}_{15} \mathrm{H}_{22} \mathrm{O}$ & $32663-57-3$ & 218 & $1595(1592)$ & MS, RI & ND & 0.66 & 0.75 \\
\hline 36 & 35.94 & $\beta$-Santalol & $\mathrm{C}_{15} \mathrm{H}_{24} \mathrm{O}$ & $37172-32-0$ & 220 & 1602 & MS & 2.25 & 0.53 & 0.66 \\
\hline 37 & 36.35 & Cubenol & $\mathrm{C}_{15} \mathrm{H}_{26} \mathrm{O}$ & $21284-22-0$ & 222 & $1613(1613)$ & MS, RI & 0.18 & 0.79 & 0.76 \\
\hline 38 & 36.54 & (Z)- $\alpha$-Santalol & $\mathrm{C}_{15} \mathrm{H}_{24} \mathrm{O}$ & $115-71-9$ & 220 & 1618 & MS & 0.28 & ND & 0.52 \\
\hline 39 & 37.38 & Torreyol & $\mathrm{C}_{15} \mathrm{H}_{26} \mathrm{O}$ & $19435-97-3$ & 222 & $1639(1640)$ & MS, RI & 0.28 & 0.45 & 0.51 \\
\hline 40 & 37.40 & $\beta$-Eudesmol & $\mathrm{C}_{15} \mathrm{H}_{26} \mathrm{O}$ & $473-15-4$ & 222 & $1640(1648)$ & MS, RI & 1.45 & ND & ND \\
\hline 41 & 37.96 & $\alpha$-Cadinol & $\mathrm{C}_{15} \mathrm{H}_{26} \mathrm{O}$ & $481-34-5$ & 222 & $1654(1654)$ & MS, RI & ND & 3.11 & ND \\
\hline 42 & 38.19 & ar-Tumerone & $\mathrm{C}_{15} \mathrm{H}_{20} \mathrm{O}$ & $532-65-0$ & 216 & $1660(1664)$ & MS, RI & 25.78 & 31.35 & 34.69 \\
\hline 43 & 38.48 & $\alpha$-Tumerone & $\mathrm{C}_{15} \mathrm{H}_{22} \mathrm{O}$ & $180315-67-7$ & 218 & 1668 & MS & 16.16 & 21.38 & 18.66 \\
\hline 44 & 39.08 & $\alpha$-Bisabolol & $\mathrm{C}_{15} \mathrm{H}_{26} \mathrm{O}$ & $515-69-5$ & 222 & 1683(1685) & MS, RI & ND & ND & 0.65 \\
\hline 45 & 39.30 & $Z$ - $\alpha$-trans-Bergamotol & $\mathrm{C}_{15} \mathrm{H}_{24} \mathrm{O}$ & $88034-74-6$ & 220 & $1689(1697)$ & MS, RI & 4.03 & 1.56 & 1.38 \\
\hline 46 & 39.59 & Germacrone & $\mathrm{C}_{15} \mathrm{H}_{22} \mathrm{O}$ & 6902-91-6 & 218 & $1700(1697)$ & MS, RI & 2.02 & 13.32 & 15.01 \\
\hline
\end{tabular}


Deep Eutectic Solvents Pretreatment Followed by Hydrodistillation for Extraction of EO from Turmeric

Table 5 Continued.

\begin{tabular}{|c|c|c|c|c|c|c|c|c|c|c|}
\hline \multirow[b]{2}{*}{ NO. } & \multirow{2}{*}{$\begin{array}{c}\text { Retention } \\
\text { time (min) }\end{array}$} & \multirow[b]{2}{*}{ Compound name } & \multirow[b]{2}{*}{ Formula } & \multirow[b]{2}{*}{ CAS\# } & \multirow[b]{2}{*}{ MW } & \multirow[b]{2}{*}{$\mathrm{RI}^{\mathrm{a}}\left(\mathrm{RI}^{\mathrm{b}}\right)$} & \multirow{2}{*}{$\begin{array}{c}\text { ID } \\
\text { method }\end{array}$} & \multicolumn{3}{|c|}{ Relative peak area $(\%)$} \\
\hline & & & & & & & & $\begin{array}{c}\text { NADES-based } \\
\text { MAHD }\end{array}$ & MAHD & HD \\
\hline 47 & 40.76 & Zerumbone & $\mathrm{C}_{15} \mathrm{H}_{22} \mathrm{O}$ & $471-05-6$ & 218 & $1729(1733)$ & MS, RI & 0.60 & ND & ND \\
\hline 48 & 41.41 & $(-)$-Drimenol & $\mathrm{C}_{15} \mathrm{H}_{26} \mathrm{O}$ & $19078-37-6$ & 222 & $1747(1750)$ & MS, RI & ND & 0.26 & ND \\
\hline 49 & 41.99 & Aristol-9-en-8-one & $\mathrm{C}_{15} \mathrm{H}_{22} \mathrm{O}$ & $6831-17-0$ & 218 & $1765(1758)$ & MS, RI & 1.67 & 2.15 & 2.21 \\
\hline \multicolumn{4}{|c|}{ The number of certified essential oil components } & & \multicolumn{2}{|r|}{39} & \multicolumn{2}{|r|}{24} & \multicolumn{2}{|c|}{21} \\
\hline \multicolumn{4}{|c|}{ Total identified peak area (\%) } & & \multicolumn{2}{|r|}{98.22} & \multicolumn{2}{|r|}{98.17} & \multicolumn{2}{|c|}{98.56} \\
\hline \multicolumn{4}{|c|}{ The number of non-oxygenated compounds } & & \multicolumn{2}{|r|}{23} & \multicolumn{2}{|r|}{11} & \multicolumn{2}{|c|}{7} \\
\hline \multicolumn{4}{|c|}{ Total non-oxygenated compounds (\%) } & & \multicolumn{2}{|r|}{39.45} & \multicolumn{2}{|r|}{21.03} & \multicolumn{2}{|c|}{19.61} \\
\hline \multicolumn{4}{|c|}{ The number of oxygenated compounds } & & \multicolumn{2}{|r|}{16} & \multicolumn{2}{|r|}{13} & \multicolumn{2}{|c|}{14} \\
\hline \multicolumn{4}{|c|}{ Total oxygenated compounds (\%) } & & \multicolumn{2}{|r|}{58.77} & \multicolumn{2}{|r|}{77.14} & \multicolumn{2}{|c|}{78.95} \\
\hline
\end{tabular}

CAS\# Chemical Abstracts Service Registry Number;

MW molecular weight;

$\mathrm{RI}^{\mathrm{a}}$ Calculation retention index based on the DB-5MS column;

$\mathrm{RI}^{\mathrm{b}}$ Retention index in the literature;

ID identification;

ND not detected.

by means of MAHD. In HD, other major compounds of EO were $\alpha$-curcumene $(3.71 \%), \alpha$-zingiberene $(4.96 \%)$, $\beta$-sesquiphellandrene (7.14\%) and germacrone(15.01\%). The difference in the major components of turmeric EO by different ways could be observed. Only 14 chemical compositions of EO such as caryophyllene, $\alpha$-curcumene, valencene and germacrone were common in three ways. Many of compounds (e.g., ylangene, $\alpha$-himachalene, $\alpha$-gurjunene and $\beta$-eudesmol) were only detected after the pretreatment of NADESs. It proved that NADESs with the dissolution ability to biomaterials could lead to a better release of the active and valuable ingredients embedded in plant matrices. In addition, the EOs of isolated either by MAHD or HD were rather similar in their composition with a few differences in their quantity (relative peak area). The chemical compositions of EOs obtained by HD and MAHD had some differences as well as similarities with the cases reported in other regions ${ }^{43-45)}$. Hence, geographical origin of turmeric appeared to have great influence on the EO qualit $^{46}{ }^{4}$. Wide variations were found in the EO obtained in NADES-based MAHD method by comparison with those reported in other literatures ${ }^{47-49)}$. Including extraction and analysis methods, the huge differences in the oil chemical profile might be also due to genotype, variety, differential geography, climate, season, cultivation practices, fertilizer application, stress during growth or maturity, harvesting time, stage of maturity and storage ${ }^{50-52)}$. It was worth noting that the number of oxygenated compounds in NADES-based MAHD remained at a relatively high level in comparison with other two methods. Oxygenated compounds in terms of their contribution to the fragrance of the plant are more valuable than monoterpenes hydrocarbons ${ }^{53)}$. Therefore, this novel technology had great potential for a much better production of natural EO that were rich in the valuable oxygenated compounds from aromatic plant materials.

\section{Conclusions}

From the experiment, synthesis of NADESs by microwave-assisted method could save the synthesis time and energy. Comparing with the traditional synthesis methods, both two methods had similar values of EO yield. It showed that microwave irradiation was a promising technique to synthesize NADESs. To get more EO yields from turmeric, NADESs by microwave-assisted preparation were as pretreatment solvents coupled with microwave-assisted HD for the extraction of EO from turmeric. The main extraction parameters such as pretreatment time, pretreatment temperature and HD time were optimized through CCD of the RSM. Under the optimal conditions, NADES composed of choline chloride and oxalic acid with a component molar ratio of 1:1 and an amount of $60 \mathrm{~g}$ in NADES obtained the highest EO yield of $0.85 \%$. By GC-MS analysis, a total of 49 compounds were identified. The number of total compounds including valuable oxygenated compounds obtained by NADES-based MAHD were higher than other two methods. In brief, the proposed method brought about more identified compounds and EO yields than MAHD and HD methods.

Such a powerful approach can provide an energy efficient and environment friendly process and a more detailed insight on the volatile fraction of turmeric to satisfy the needs of the food and fragrance industries. 


\section{Conflict of Interest}

The authors declare that there is no conflict of interests regarding the publication of this paper.

\section{Acknowledgement}

This work was made possible with funding provided by the Natural Science Foundation of Zhejiang Province (LZY21E030001), the Xinmiao Talents Program of Zhejiang Province(2020R403051), National College Student Innovation and Entrepreneurship Training Program (202010337034) and the General Research Project of Department of Education of Zhejiang Province(Y202043157).

\section{References}

1) Parizotto, C.A.; Dall' Oglio, E.L.; de Vasconcelos, L.G.; de Sousa, P.T.; Taques, E.G.R.; Kuhnen, C.A. Measuring dielectric properties for microwave-assisted extraction of essential oils using single-mode and multimode reactors. Rsc Adv. 9, 5259-5269 (2019).

2) Jayaprakasha, G.K.; Rao, L.J.M.; Sakariah, K.K. Improved HPLC method for the determination of curcumin, demethoxycurcumin, and bisdemethoxycurcumin. J. Agric. Food Chem. 50, 3668-3672 (2002).

3) Ayati, Z.; Ramezani, M.; Amiri, M.S.; Moghada, A.T.; Rahimi, H.; Abdollahzade, A.; Sahebkar, A.; Emami, S.A. Ethnobotany, phytochemistry and traditional uses of Curcuma spp. and pharmacological profile of two important species (C. longa and C. zedoaria): A review. Curr. Pharm. Des. 25, 871-935(2019).

4) Ayodele, J.A.; Oluwabamise, L.F.; Awonegan, A.P.; Israel, O.; Opeyemi, A.F.; Titus, A.O. Nephroprotective effect of essential oils from ginger (Zingiber officinale) and turmeric (Curcuma longa) rhizomes against cadmium-induced nephrotoxicity in rats. J. Oleo Sci. 67, 1339-1345(2018).

5) Al-Okbi, S.Y.; El-qousy, S.M.; El-Ghlban, S.; Moawad, H.F. Role of borage seed oil and fish oil with or without turmeric and alpha-tocopherol in prevention of cardiovascular disease and fatty liver in rats. J. Oleo Sci. 67, 1551-1562 (2018).

6) Kazuko, I.; Hirokazu, K.; Fumiaki, T.; Shinichi, M.; Ikuto, A.; Tatsuya, M.; Nobuhiro, Z. Mixing Ginkgo biloba extract with sesame extract and turmeric oil increases bioavailability of ginkgolide A in mice brain. J. Oleo Sci. 68, 923-930(2019).

7) Tongnuanchan, P.; Benjakul, S. Essential oils: Extraction, bioactivities, and their uses for food preservation. J. Food Sci. 79, 1231-1249 (2014).

8) Giacometti, J.; Kovacevic, D.B.; Putnik, P.; Gabric, D.; Bilusic, T.; Kresic, G.; Stulic, V.; Barba, F.J.; Chemat, F.;
Barbosa-Canovas, G.; Jambrak, A.R. Extraction of bioactive compounds and essential oils from mediterranean herbs by conventional and green innovative techniques: A review. Food Res. Int. 113, 245-262(2018).

9) Manouchehri, R.; Saharkhiz, M.J.; Karami, A.; Niakousari, M. Extraction of essential oils from damask rose using green and conventional techniques: Microwave and ohmic assisted hydrodistillation versus hydrodistillation. Sustain. Chem. Pharm. 8, 76-81(2018).

10) Farhat, A.; Fabiano-Tixier, A.S.; El Maataoui, M.; Maingonnat, J.F.; Romdhane, M.; Chemat, F. Microwave steam diffusion for extraction of essential oil from orange peel: Kinetic data, extract's global yield and mechanism. Food Chem. 125, 255-261 (2011).

11) Bousbia, N.; Vian, M.A.; Ferhat, M.A.; Meklati, B.Y.; Chemat, F. A new process for extraction of essential oil from Citrus peels: Microwave hydrodiffusion and gravity. J. Food Eng. 90, 409-413(2009).

12) Liu, Z.Z.; Deng, B.Q.; Li, S.L.; Zou, Z.R. Optimization of solvent-free microwave assisted extraction of essential oil from Cinnamomum camphora leaves. Ind. Crops Prod. 124, 353-362 (2018).

13) Aguilar-Reynosa, A.; Romani, A.; Rodriguez-Jasso, R.M.; Aguilar, C.N.; Garrote, G.; Ruiz, H.A. Microwave heating processing as alternative of pretreatment in second-generation biorefinery: An overview. Energy Convers. Manage. 136, 50-65(2017).

14) Kumari, D.; Singh, R. Pretreatment of lignocellulosic wastes for biofuel production: A critical review. $R e-$ new. Sust. Energ. Rev. 90, 877-891 (2018).

15) Abbott, A.P.; Capper, G.; Davies, D.L.; Rasheed, R.K.; Tambyrajah, V. Novel solvent properties of choline chloride/urea mixtures. Chem. Commun. 1, 70-71 (2003).

16) Patil, S.S.; Pathak, A.; Rathod, V.K. Optimization and kinetic study of ultrasound assisted deep eutectic solvent based extraction: A greener route for extraction of curcuminoids from Curcuma longa. Ultrason. Sonochem. 70, 105267 (2021).

17) Smith, E.L.; Abbott, A.P.; Ryder, K.S. Deep eutectic solvents (DESs) and their applications. Chem. Rev. 114, 11060-11082(2014).

18) Zhang, Y.Y.; Lu, X.H.; Feng, X.; Shi, Y.J.; Ji, X.Y. Properties and applications of choline-based deep eutectic solvents. Prog. Chem. 25, 881-892(2013).

19) Yu, G.W.; Cheng, Q.; Nie, J.; Wang, P.; Wang, X.J.; Li, Z.G.; Lee, M.R. DES-based microwave hydrodistillation coupled with GC-MS for analysis of essential oil from black pepper (Piper nigrum) and white pepper. Anal. Methods 9, 6777-6784(2017).

20) Zhao, Y.P.; Wang, P.; Zheng, W.; Yu, G.W.; Li, Z.G.; She, Y.B.; Lee, M. Three-stage microwave extraction of cumin (Cuminum cyminum L.) Seed essential oil with natural deep eutectic solvents. Ind. Crops Prod. 
140, 111660 (2019).

21) Thi, S.; Lee, K.M. Comparison of deep eutectic solvents (DES) on pretreatment of oil palm empty fruit bunch (OPEFB): Cellulose digestibility, structural and morphology. Bioresour. Technol. 282, 525-529 (2019).

22) Dai, Y.T.; Witkamp, G.J.; Verpoorte, R.; Choi, Y.H. Natural deep eutectic solvents as a new extraction media for phenolic metabolites in Carthamus tinctorius L. Anal. Chem. 85, 6272-6278(2013).

23) Jelinski, T.; Przybylek, M.; Cysewski, P. Natural deep eutectic solvents as agents for improving solubility, stability and delivery of curcumin. Pharm. Res. 36, 1-10 (2019).

24) Liu, Y.H.; Li, J.; Fu, R.Z.; Zhang, L.L.; Wang, D.Z.; Wang, S. Enhanced extraction of natural pigments from Curcuma longa L. using natural deep eutectic solvents. Ind. Crops Prod. 140, 111620 (2019).

25) Nie, J.; Yu, G.W.; Song, Z.Y.; Wang, X.J.; Li, Z.G.; She, Y.B.; Lee, M. Microwave-assisted deep eutectic solvent extraction coupled with headspace solid-phase microextraction followed by GC-MS for the analysis of volatile compounds from tobacco. Anal. Methods 9, 856863 (2017).

26) Dai, Y.T., van Spronsen, J., Witkamp, G.J., Verpoorte, R., Choi, Y.H. Natural deep eutectic solvents as new potential media for green technology. Anal. Chim. Acta 766, 61-68(2013).

27) Gutierrez, M.C.; Ferrer, M.L.; Mateo, C.R.; del Monte, F. Freeze-drying of aqueous solutions of deep eutectic solvents: A suitable approach to deep eutectic suspensions of self-assembled structures. Langmuir 25, 5509-5515 (2009).

28) Wang, J.L.; Bao, A.J.; Meng, X.H.; Guo, H.Y.; Zhang, Y.D.; Zhao, Y.L.; Kong, W.B.; Liang, J.Y.; Yao, J.; Zhang, J. An efficient approach to prepare sulfated polysaccharide and evaluation of anti-tumor activities in vitro. Carbohydr. Polym. 184, 366-375 (2018).

29) Ozturk, B.; Parkinson, C.; Gonzalez-Miquel, M. Extraction of polyphenolic antioxidants from orange peel waste using deep eutectic solvents. Sep. Purif. Technol. 206, 1-13 (2018).

30) Abedi, A.S.; Rismanchi, M.; Shahdoostkhany, M.; Mohammadi, A.; Mortazavian, A.M. Microwave-assisted extraction of Nigella sativa L. essential oil and evaluation of its antioxidant activity. J. Food Sci. Technol.Mysore. 54, 3779-3790 (2017).

31) Feng, X.F.; Jing, N.; Li, Z.G.; Wei, D.; Lee, M.R. Ultrasound-microwave hybrid-assisted extraction coupled to headspace solid-phase microextraction for fast analysis of essential oil in dry traditional Chinese medicine by GC-MS. Chromatographia 77, 619-628 (2014).

32） Nam, M.W.; Zhao, J.; Lee, M.S.; Jeong, J.H.; Lee, J. En- hanced extraction of bioactive natural products using tailor-made deep eutectic solvents: application to flavonoid extraction from Flos sophorae. Green Chem. 17, 1718-1727 (2015).

33) Makos, P.; Fernandes, A.; Przyjazny, A.; Boczkaj, G. Sample preparation procedure using extraction and derivatization of carboxylic acids from aqueous samples by means of deep eutectic solvents for gas chromatographic-mass spectrometric analysis. J. Chromatogr. A 1555, 10-19 (2018).

34) Mao, C.F.; Zhao, R.X.; Li, X.P. High removal rate of sulfur in model oil by $\mathrm{ChCl} / \mathrm{H} 2 \mathrm{C} 204$ deep eutectic solvents. Chemical Engineering (China)45, 6-10 (2017).

35) Alvarez-Vasco, C.; Ma, R.S.; Quintero, M.; Guo, M.; Geleynse, S.; Ramasamy, K.K.; Wolcott, M.; Zhang, X. Unique low-molecular-weight lignin with high purity extracted from wood by deep eutectic solvents (DES): a source of lignin for valorization. Green Chem. 18, 5133-5141 (2016).

36) Zhu, C.P.; Liu, X.L. Optimization of extraction process of crude polysaccharides from Pomegranate peel by response surface methodology. Carbohydr. Polym. 92, 1197-1202 (2013).

37) Wang, S.J.; Chen, F.; Wu, J.H.; Wang, Z.F.; Liao, X.J.; $\mathrm{Hu}, \mathrm{X} . \mathrm{S}$. Optimization of pectin extraction assisted by microwave from apple pomace using response surface methodology. J. Food Eng. 78, 693-700 (2007).

38) Mollaei, S.; Sedighi, F.; Habibi, B.; Hazrati, S.; Asgharian, P. Extraction of essential oils of Ferulago angulata with microwave-assisted hydrodistillation. Ind. Crops Prod. 137, 43-51 (2019).

39) Hong, S.; Song, Y.D.; Yuan, Y.; Lian, H.L.; Liimatainen, H. Production and characterization of lignin containing nanocellulose from luffa through an acidic deep eutectic solvent treatment and systematic fractionation. Ind. Crops Prod. 143, 1-8(2020).

40) Garcia, G.; Aparicio, S.; Ullah, R.; Atilhan, M. Deep eutectic solvents: Physicochemical properties and gas separation applications. Energy Fuels 29, 2616-2644 (2015).

41) Zhang, L.Y.; Yang, Z.W.; Chen, F.; Su, P.; Chen, D.K.; Pan, W.Y.; Fang, Y.X.; Dong, C.Z.; Zheng, X.; Du, Z.Y. Composition and bioactivity assessment of essential oils of Curcuma longa L. collected in China. Ind. Crops Prod. 109, 60-73(2017).

42) Priyanka; Khanam, S. Influence of operating parameters on supercritical fluid extraction of essential oil from turmeric root. J. Clean Prod. 188, 816-824 (2018).

43) Dosoky, N.S.; Setzer, W.N. Chemical composition and biological activities of essential oils of Curcuma species. Nutrients 10, 1-42 (2018).

44） Mishra, R.; Gupta, A.K.; Kumar, A.; Lal, R.K.; Saikia, D.; 
Chanotiya, C.S. Genetic diversity, essential oil composition, and in vitro antioxidant and antimicrobial activity of Curcuma longa L. germplasm collections. $J$. Appl. Res. Med. Aromat. Plants 10, 75-84 (2018).

45) Sahoo, A.; Kar, B.; Jena, S.; Dash, B.; Ray, A.; Sahoo, S.; Nayak, S. Qualitative and quantitative evaluation of rhizome essential oil of eight different cultivars of Curcuma longa L. (Turmeric). J. Essent. Oil Bear. Plants 22, 239-247 (2019).

46) Mazloomifar, H.; Saber-Tehrani, M.; Rustaiyan, A.; Masoudi, S. Essential oil of Cleome coluteoides Boiss. from Iran. J. Essent. Oil Res. 15, 337-338(2003).

47) Jayashree, E.; Zachariah, T.J. Processing of turmeric (Curcuma longa) by different curing methods and its effect on quality. Indian J. Agric. Sci. 86, 696-698 (2016).

48) Purkayastha, J.; Nath, S.C.; Klinkby, N. Essential oil of the rhizome of Curcuma zedoaria (Christm.) Rosc. native to northeast India. J. Essent. Oil Res. 18, 154155 (2006).

49) Zhang, L.Y.; Yang, Z.W.; Wei, J.W.; Su, P.; Pan, W.Y.;
Zheng, X.; Zhang, K.; Lin, L.; Tang, J.; Fang, Y.X.; Du, Z. Essential oil composition and bioactivity variation in wild-growing populations of Curcuma phaeocaulis Valeton collected from China. Ind. Crops Prod. 103, 274-282 (2017).

50) Burt, S. Essential oils: their antibacterial properties and potential applications in foods - A review. Int. J. Food Microbiol. 94, 223-253 (2004).

51) Sandeep, I.S.; Sanghamitra, N.; Sujata, M. Differential effect of soil and environment on metabolic expression of turmeric (Curcuma longa cv. Roma). Indian J. Exp. Biol. 53, 406-411 (2015).

52) Srinivasan, V.; Thankamani, C.K.; Dinesh, R.; Kandiannan, K.; Zachariah, T.J.; Leela, N.K.; Hamza, S.; Shajina, O.; Ansha, O. Nutrient management systems in turmeric: Effects on soil quality, rhizome yield and quality. Ind. Crops Prod. 85, 241-250 (2016).

53) Ferhat, M.A.; Meklati, B.Y.; Smadja, J.; Chemat, F. An improved microwave Clevenger apparatus for distillation of essential oils from orange peel. J. Chromatogr. A 1112, 121-126 (2006). 